\title{
STALIŠČA STARŠEV V PORABJU DO SLOVENSKEGA JEZIKA
}

\section{Katalin MUNDA HIRNÖK}

Inštitut za narodnostna vprašanja, Ljubljana

Munda Hirnök, K. (2017): Stališča staršev v Porabju do slovenskega jezika. Slovenščina 2.o, 2017 (2): $33-63$.

DOI: http://dx.doi.org/10.4312/slo2.0.2017.2.33-63.

Inštitut za narodnostna vprašanja, Ljubljana

Prispevek je nastal na podlagi analize kvantitativne raziskave z naslovom Stališča staršev $v$ Porabju do slovenskega jezika oziroma dvo- in večjezičnosti ter tudi preteklih raziskav, strokovne literature in terenskih izkušenj. Študija prikazuje stališča porabskih Slovencev (staršev otrok, ki obiskujejo narodnostne vrtce) do slovenskega jezika (in drugih jezikov) in na drugi strani išče odgovore na vprašanje, zakaj je prišlo do prekinitve prenosa slovenske materinščine na anketirane - starše in posledično na najmlajše. Podatki kažejo, da si stališča in raba jezika v družini ter rezultati pri vprašanju, zakaj se vprašanim staršem zdi znanje slovenskega jezika pomembno za otroka, nasprotujejo. Med odgovori na vprašanje, zakaj se starši z otroki doma ne pogovarjajo porabsko/slovensko, izstopa mnenje, da starši in mladi ne znajo jezika in da ni medgeneracijskega prenosa. Pozitivna stališča staršev do slovenskega jezika so lahko dobra podlaga za revitalizacijo porabščine/slovenskega jezika v Porabju.

Ključne besede: Madžarska, Porabje, slovenska manjšina, slovenski jezik, stališča do jezika

\section{UVOD}

Različne zgodovinske in politične okoliščine so zaznamovale slovensko Porabje in vplivale tudi na jezik oziroma jezikovno identiteto porabskih Slovencev. Prebivalci na območju današnjega Prekmurja in Porabja so delili skupno usodo v ogrskem delu habsburške monarhije vse do prve svetovne vojne. S trianonsko mirovno pogodbo je bilo Prekmurje priključeno h Kraljevini Srbov, Hrvatov in 
Slovencev (pozneje Kraljevina Jugoslavija), devet vasi Porabja pa je ostalo v madžarski državi ${ }^{1}$ in med ljudmi, ki so jih po narodnosti dojemali kot »drugačne«. Porabščina se je govorila v zasebni sferi in cerkvi, ker so bili duhovniki pretežno domačini. Uradovalni jezik pa je bil ves čas le madžarščina, zato porabsko narečje nima lastnega upravno-pravnega besedišča. V porabskih šolah so imeli med obema vojnama pri pouku porabskega narečja na voljo prekmurske učbenike, pisane v madžarski grafiki (Perger 2009: 344). Za odnos večine do manjšinskih jezikov v izobraževalnem procesu je bilo značilno, da jih je marginalizirala in izpostavljala pomembnost usvojitve večinskega jezika (Bernjak 2012: 104).

Po drugi svetovni vojni je zaradi zaostritve političnih odnosov med Madžarsko in Jugoslavijo prišlo do oblikovanja t. i. železne zavese, ki je za več desetletij otežila oziroma onemogočila stike prebivalcev Porabja z bližnjim prekmurskim jezikovnim prostorom, zato je razvoj porabskega narečja potekal nekoliko drugače in je danes podnarečje prekmurščine. Izoliranost obmejnega območja je kljub strogemu vojaškemu režimu omogočala rabo in ohranjanje porabskega narečja. Porabščina se je še naprej ohranjala v družini, cerkvi in soseski. Slovenščina se je začela oživljati v šoli v šestdesetih letih prejšnjega stoletja. Tudi sosedski odnosi med Madžarsko in Slovenijo so oživeli. Prebivalci slovenskih vasi so se začeli zaposlovati v Monoštru. Na začetku je šlo za dnevne migracije, sčasoma pa so se dnevne migracije spremenile $\mathrm{v}$ trajno izselitev. Zaradi slabih gospodarskih razmer so ljudje odhajali tudi na sezonsko delo na oddaljena madžarska posestva (Munda Hirnök 1992: 238-248).

S postopnim odpiranjem obmejnega območja so se pojavili dejavniki, ki so v glavnem enojezično slovensko skupnost načeli. Madžarščina je vedno bolj

\footnotetext{
${ }_{1}^{1}$ Devet slovenskih vasi v okolici Monoštra je bilo dodeljenih Madžarski: Andovci (Orfalu), Dolnji Senik (Alsószölnök), Gornji Senik (Felsőszölnök), Sakalovci (Szakonyfalu), Slovenska ves (Rábatótfalu), Števanovci (Apátistvánfalva), Otkovci (Balázsfalu) - vas je bila leta 1937 priključena Števanovcem, Vérica in Ritkarovci (Kétvölgy) - vasi sta se združili leta 1951. V teh vaseh so prebivali pretežno prebivalci slovenskega rodu, skupaj z Nemci, Madžari in Romi. O tem glej podrobneje: Kovács 2007: 41-73.
} 
prodirala v vaško okolje. Cerkveni obredi so sicer potekali v narečju, šola pa je bila pretežno madžarska. Knjižno slovenščino so poučevali le nekaj ur tedensko. Popolnoma madžarsko pa je bilo okolje, kamor so ljudje odhajali na delo. Tam so se srečali s težavami zaradi pomanjkljivega znanja madžarskega jezika, sodelavci in nadrejeni so se jim nemalokrat posmehovali. Posledično so se začeli pospešeno učiti madžarsko, naslednji korak pa je bil, da so se starši zavestno začeli pogovarjati s svojimi otroki madžarsko, da bi jih obvarovali frustracij, ki so jih sami doživljali. Rezultat teh procesov je opuščanje materinščine in prevlada madžarskega jezika.

V obdobju tranzicije je porabsko narečje deloma ostalo jezik verskega obredja, po letu 1990 tudi jezik narodnostnih medijev (ob knjižni slovenščini) in do neke mere tudi javnega življenja, $\mathrm{v}$ porabskih šolah pa most do slovenskega standardnega (knjižnega) jezika (Just 2009: 28; Perger 2009: 345-346). Kljub izoblikovani institucionalni podpori slovenski manjšini po demokratičnih spremembah na Madžarskem, ${ }^{2}$ ki omogoča ohranjanje etnične identitete ter jezika, so se istočasno izoblikovale družbene in ekonomske razmere, ki niso in ne vplivajo spodbujevalno na ohranjanje slovenskega jezika. 3 Raba porabščine/slovenščine je danes močno okrnjena in je v družinah zmeraj manj prisotna. Izsledki preteklih in novejših raziskav ter terenske izkušnje namreč kažejo, da je prenos domačega jezika s staršev na otroke skoraj povsem pretrgan, trgajo se tudi jezikovne vezi med starimi starši in vnuki. Madžarščina vse bolj pridobiva funkcijo sporazumevalnega jezika v družinah (Nećak Lük 1998: 48; Munda Hirnök in Novak Lukanovič 2016). Raziskovalci jezikovnega

\footnotetext{
${ }_{2}$ Po spremembi političnega sistema na Madžarskem opažamo pozitivne premike, kar zadeva institucionalno podporo manjšinskemu jeziku na področjih, kot so: 1. mediji (izhajanje tednika Porabje - od leta 1991, uvedba televizijske oddaje Slovenski utrinki - od leta 1992, ustanovitev Radia Monošter - od leta 2000; 2. publicistična dejavnost; 3. kulturna in politična organiziranost slovenske narodne skupnosti v Porabju in mestnih jedrih zunaj Porabja.

3 Zaradi prisotnosti tujega kapitala $\mathrm{v}$ Monoštru in bolje plačanih delovnih mest $\mathrm{v}$ bližnji Avstriji prebivalci Porabja, zlasti mladi, večjo perspektivo vidijo v učenju tujih jezikov (zlasti nemščine).

(opomba se nadaljuje na naslednji strani)
} 
položaja v Porabju takšno stanje pripisujejo gospodarski, kulturni in jezikovni izoliranosti Porabja od matične države ter močni, bolj ali manj prikriti asimilacijski politiki večinske družbe v preteklosti (Nećak Lük 2008: 67; Bernjak 2012: 104). Madžarska je šele s sprejetjem Ustave (1989)4 ter Zakona o pravicah narodnih in etničnih manjšin (1993) začela pri reševanju manjšinskih vprašanj dosledneje upoštevati določbe mednarodnega prava in ostalih mednarodnih dokumentov o zaščiti manjšin. Do danes so se ustvarile relativno ugodne razmere za institucionalno ureditev statusa manjšinskih jezikov, tudi slovenskega. Uresničevanje pravnih podlag v zvezi z rabo jezika v konkretnem življenju pa je v veliki meri odvisno od manjšine same in njene vitalnosti. $\mathrm{V}$ prispevku, ki je nastal na podlagi izvedene kvantitativne raziskave Stališča staršev v Porabju do slovenskega jezika oziroma dvo- in večjezičnosti (2016)5 ter tudi preteklih raziskav, strokovne literature in terenskih izkušenj, želimo prikazati stališča porabskih Slovencev (staršev otrok, ki obiskujejo narodnostne vrtce) do manjšinskega jezika (in drugih jezikov) ter do prisotnosti slovenskega jezika $\mathrm{v}$ vrtcih in ugotoviti vzroke za prekinitev slovenske jezikovne kontinuitete. Pomembno je poudariti, da so se dosedanje raziskave in aktivnosti pretežno osredotočale na šolo, učence in učitelje, ${ }^{6}$ nekoliko manj pa na starše oziroma vlogo družine pri prenosu slovenske materinščine na otroke.

\footnotetext{
4 Tukaj je treba pripomniti, da je bila leta 2011 sprejeta nova ustava. Pred sprejetjem omenjene ustave je veljala ustava še iz leta 1949, ki je bila prvič spremenjena in dopolnjena leta 1972, nato pa še leta 1989 ob spremembi družbenega sistema.

5 Raziskava Stališča staršev v Porabju do slovenskega jezika oziroma dvo- in večjezičnosti je potekala na Inštitutu za narodnostna vprašanja v letu 2016. Nosilka raziskave: dr. Katalin Munda Hirnök. Sodelavki: dr. Sonja Novak Lukanovič in dr. Mojca Medvešek. Financer: Urad Vlade RS za Slovence v zamejstvu in po svetu. Projekt se nadaljuje v letu 2017.

${ }^{6}$ Glej npr. raziskavo Narodnostno šolstvo v Porabju: dejansko stanje in perspektive (2006), ki je potekala na Inštitutu za narodnostna vprašanja pod vodstvom dr. Katalin Munda Hirnök.
} 
2 RAZISKAVA O STALIŠČIH STARŠEV V PORABJU DO SLOVENSKEGA JEZIKA OZIROMA DVO- IN VEČJEZIČNOSTI

\subsection{Metodologija raziskave}

Pri izvedbi raziskave Stališča staršev v Porabju do slovenskega jezika oziroma dvo- in večjezičnosti smo uporabili kvantitativno metodo anketiranja $\mathrm{s}$ strukturiranim vprašalnikom. V vzorec smo vključili starše vseh otrok, ki obiskujejo narodnostne vrtce na Dolnjem Seniku, Gornjem Seniku, v Sakalovcih in Števanovcih, ter t. i. slovensko vrtčevsko skupino v Monoštru. Pripravili smo strukturiran vprašalnik s 16 vprašanji zaprtega in odprtega tipa v slovenskem in madžarskem jeziku. Vprašanja, s pomočjo katerih smo želeli evidentirati stališča staršev do slovenskega jezika oziroma dvo- in večjezičnosti, so bila: demografski podatki anketiranega, narodna oziroma etnična pripadnost, materni jezik, raba jezika $\mathrm{v}$ družini, stališča anketiranih o programih in jezikih v vrtcih, stališča o pomembnosti učenja slovenskega jezika za otroke, samoocena znanja jezikov, stališča do jezikov in razlogi, zakaj se v Porabju starši z otroki doma ne pogovarjajo slovensko/porabsko.

Anketiranje je potekalo od 18. do 25. novembra 2016. S pomočjo vodstva vrtcev smo staršem razdelili 79 vprašalnikov, od katerih jih je bilo vrnjenih 67 , kar je 84,8-odstotni odziv. Število anketiranih po krajih, kjer je bila izvedena anketa, je naslednje: 14 (20,9 \%) oseb je bilo z Dolnjega Senika, 13 (19,4 \%) oseb z Gornjega Senika, 19 (28,4 \%) oseb iz Monoštra, 10 (14,9 \%) oseb iz Sakalovcev in $11(16,4$ \%) oseb iz Števanovcev. Večina anketiranih je vprašalnik izpolnila v madžarskem jeziku.7 V anketi je sodelovalo 56 (83,6 \%) žensk in 10 (14,9 \%) moških. Med anketiranimi v največjem deležu (71,6 \%) najdemo osebe, stare od 31 do 45 let, 14,9 \% anketiranih je bilo starih do 30 let, $6 \%$ anketiranih je bilo starih nad 45 let, 7,5 \% anketiranih pa ni navedlo podatka o starosti. Izobrazbena sestava anketiranih kaže, da med njimi prevladujejo anketirani s

7 Le 4 anketirani so izpolnili vprašalnik v obeh jezikih. Samo slovensko izpolnjene ankete ni bilo. 
končano poklicno $(47,8 \%)$ in srednjo šolo (23,9\%). Visoko oziroma fakultetno izobraženih je 17,9 \% anketiranih, najmanj anketiranih (10,4 \%) pa ima končano osnovno šolo. Med anketirani se jih je največ, to je $43(64,2 \%)$, opredelilo za Madžare, 17 (25,4 \%) anketiranih se je opredelilo za Slovence in Madžare, 5 (7,5 \%) anketiranih za Slovence, 2 (3\%) anketirana pa nista želela odgovoriti na vprašanje. Podatek, da se je četrtina vprašanih opredelila za večplastno identiteto, nas ne preseneča. Strokovnjaki so namreč mnenja, da pripadniki manjšine $\mathrm{v}$ procesu socializacije sprejemajo vsebine lastne identitete in elemente identitete večinskega naroda oziroma družbe, $v$ katero so vključeni prek različnih ustanov (gospodarskih, političnih, izobraževalnih in kulturnih). Proces socializacije zaradi omenjene dvotirnosti objektivno pelje v večplastnost identitete, kar je druga značilnost identitete pripadnikov manjšin (Zupančič 1999: 72). Tudi novejše raziskave, ki smo jih izvedli v Porabju, kažejo povečanje števila oseb z večplastno identiteto (prim. Munda Hirnök in Medvešek 2016: 98). Podatek, da so samo 4 anketirani izpolnili vprašalnik v obeh jezikih, samo slovenske ankete pa nihče, potrjuje ugotovitve jezikoslovcev glede jezikovnega položaja v Porabju, in sicer »da je mlajša generacija pogosto poljezična v jeziku manjšine ali povsem enojezična $\mathrm{v}$ jeziku večine« (Bernjak 2008: 51). Tudi raziskava o mladih v slovenskem zamejstvu kaže,${ }^{8}$ da slovenski jezik pri mladih v Porabju izgublja vlogo osrednjega identitetnega kazalnika.

\subsection{Analiza podatkov}

V raziskavi Stališča staršev $v$ Porabju do slovenskega jezika oziroma dvo- in večjezičnosti nas je najprej zanimala samoopredelitev anketiranih staršev glede njihovega maternega jezika (tj. jezika, ki so ga začeli govoriti najprej) (Slika 1).

Največ anketiranih, in sicer skoraj 75 \%, je navedlo, da je njihov materni jezik madžarščina. Slaba desetina se jih je opredelila za madžarščino in slovenščino,

\footnotetext{
8 Raziskovalni projekt Mladi $v$ slovenskem zamejstvu: družbeni in kulturni konteksti ter sodobni izzivi je potekal na Inštitutu za narodnostna vprašanja v letih 2013-2016. Vodila ga je dr. Vera Kržišnik - Bukić.
} 
$3 \%$ za slovenski jezik in prav tako 3 \% za porabsko narečje - madžarski jezik. Desetina pa jih ni želela odgovoriti na to vprašanje.

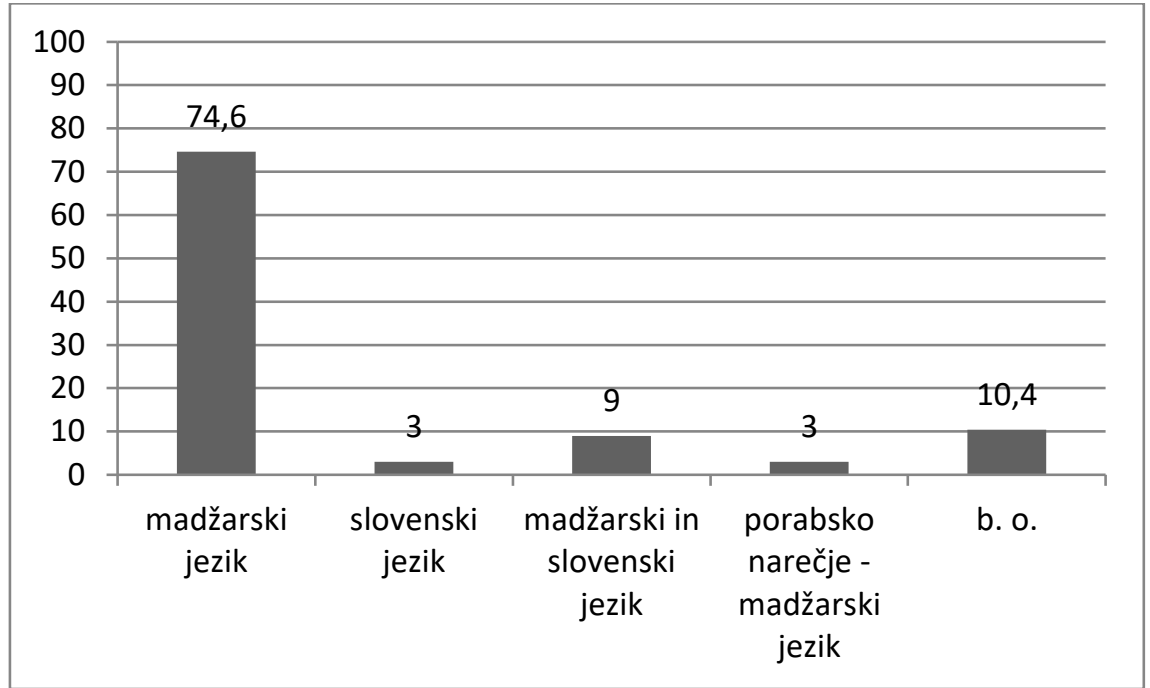

Slika 1: Anketirani: materni jezik staršev (izraženo v odstotkih, $N=67$ ).

Odgovori anketiranih na vprašanje, kateri jezik govorijo, pri čemer je bilo možnih več odgovorov, kažejo (Slika 2) močno prevlado večinskega jezika nad ostalimi jeziki. Večina, 92,5 \% vprašanih, govori madžarsko, slovenski (knjižni) jezik govori skromnih $13 \%$, porabsko narečje približno tretjina $(34,3 \%)$, nemški jezik $37 \%$, angleški jezik pa zanemarljivih 7,5 \%. Na to vprašanje ni odgovorila dobra desetina anketiranih. 


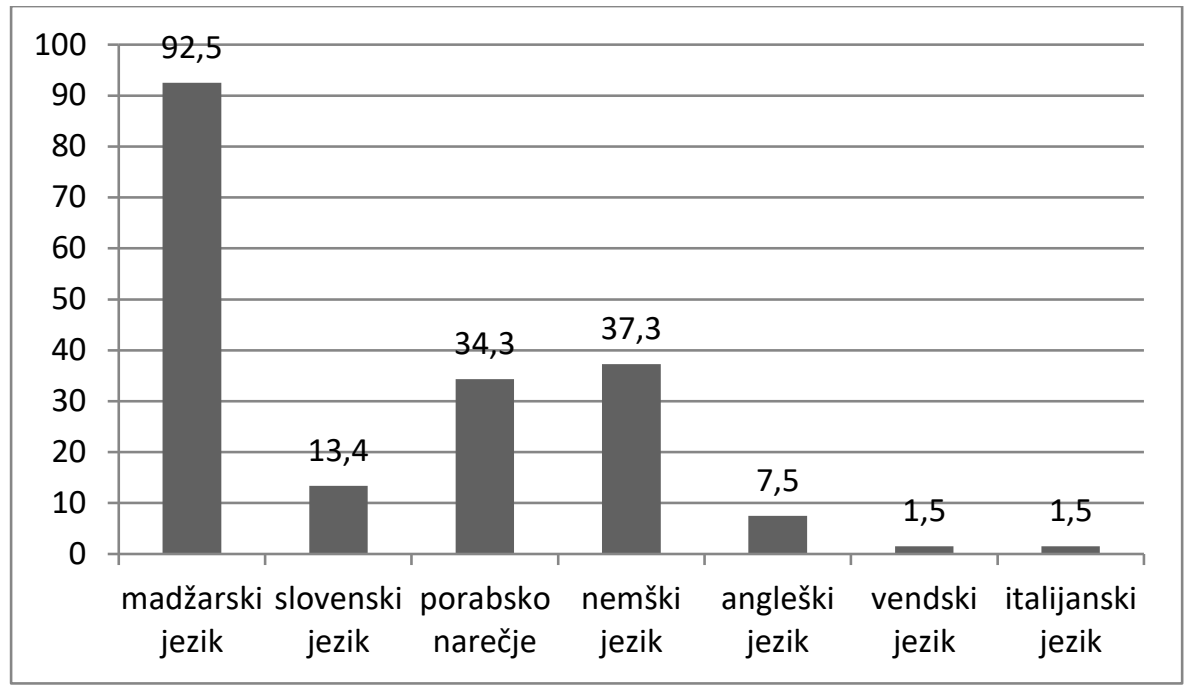

Slika 2: Odgovori na vprašanje, kateri jezik govorijo - možnih je bilo več odgovorov (izraženo v odstotkih, $\mathrm{N}=67$ ).

V preteklosti slovenski jezik v Porabju ni imel ustreznega položaja. Šele v zadnjem obdobju smo priča pozitivnim spremembam, ko govorimo o organizaciji poučevanja slovenskega jezika (Perger 2016/2017).9

Podatki o samooceni znanja jezikov (Slika 3) kažejo, da med jeziki močno izstopa večinski jezik. Skoraj vsi anketirani, to je $98,5 \%$, so svoje znanje madžarščine ocenili kot zelo dobro oziroma dobro. Vsi ostali jeziki so bili znatno slabše ocenjeni. 16,4 \% anketiranih je svoje znanje porabskega narečja ocenilo kot zelo dobro oziroma dobro, slaba četrtina (22,4\%) kot srednje dobro, slaba polovica (43,3\%) pa je odgovorila, da porabsko narečje obvlada slabo oziroma zelo slabo. Anketirani so znanje nemščine ovrednotili približno enako kot znanje porabščine. Znanje knjižne slovenščine so v primerjavi s porabščino

\footnotetext{
9 V Porabju je danes učenje slovenskega jezika v različnih oblikah (dvojezični pouk, t.i. narodnostni pouk slovenskega jezika, fakultativni pouk/krožek) možno v štirih narodnostnih vrtcih, v Monoštru imajo t. i. slovensko vrtčevsko skupino, na dvojezičnih šolah (DOŠ Jožefa Košiča Gornji Senik, DOŠ Števanovci) in na srednjih šolah (Gimnazija Mihálya Vörösmartyja, Srednja strokovna šola Béle III.) v Monoštru, kjer je možno opravljati maturo iz slovenščine. Učenje slovenskega jezika na višjih stopnjah je možno zunaj Porabja, in sicer v Sombotelu in Budimpešti. Slovenščina je v manjši meri prisotna tudi v neformalnem izobraževanju (tečaji).
} 
ocenili slabše, 7,5 \% jih je odgovorilo, da znajo dobro oziroma zelo dobro slovensko, dobra desetina srednje dobro in skoraj dve tretjini slabo oziroma zelo slabo. Še nekoliko slabše so ocenili znanje angleščine, saj je svoje znanje kot zelo dobro oziroma dobro ocenilo $3 \%$ vprašanih, 7,5 \% kot srednje dobro, skoraj 60 \% kot slabo oziroma zelo slabo, slaba tretjina pa na vprašanje ni odgovorila.

Podatki o znanju jezikov, ki smo jih uvrstili v vprašalnik, kažejo visoko stopnjo samoocene znanja madžarskega jezika pri vprašanih, kar je bilo pričakovati, saj so se anketirani socializirali v madžarsko govorečem okolju. Opazna je razlika med samooceno znanja porabskega narečja in knjižne slovenščine $\mathrm{v}$ prid porabskega narečja. Treba je dodati, da starejša generacija (večino staršev anketiranih lahko uvrstimo v to starostno skupino) zaradi že omenjenih ovir v stikih z matično državo ni spoznala in se naučila knjižne slovenščine, zato kot svojo »materno/domanjo rejč« razumejo porabsko narečje. Delež anketiranih, ki so svoje znanje porabskega narečja ocenili kot dobro ali srednje dobro, kaže, da je v njihovem primeru prišlo do medgeneracijskega prenosa porabščine $\mathbf{s}$ strani staršev. Podatek o samooceni knjižne slovenščine potrjuje, da se anketirani v vrtcu in šoli niso dovolj dobro naučili slovenskega jezika. Dobra tretjina anketiranih $(38,8 \%)$ je ocenila svoje znanje porabskega narečja kot dobro oziroma srednje dobro, znanje knjižne slovenščine pa jih je kot dobro oziroma srednje dobro ocenila dobra petina (20,9\%). Slabo znanje tujih jezikov vprašanih je treba gledati v širšem kontekstu. Po poročilu Eurostata jih med prebivalci Madžarske v starostni skupini od 25 do 64 let le 37 \% govori vsaj en tuji jezik. Ta podatek Madžarsko uvršča na zadnje mesto na lestvici. Največ Madžarov (kakor tudi prebivalcev v večini držav EU) govori angleško, toda le 25 \% jih ima dobro znanje. ${ }^{10}$ Podatki o znanju tujih jezikov vprašanih kažejo, da

$10 \quad 37 \%$ beszél idegennyelvet, de az angolt csak ...Portfolio.hu, dostopno prek: http://www.portfolio.hu/users/elofizetes_info.php?t=cikk\&i=190226 (11. 8. 2017).

Po objavi podatkov Eurostata je predsednik madžarska vlade Viktor Orbán ukazal ministru za človeške vire, naj njegovo ministrstvo evalvira pogoje in položaj pouka tujih jezikov na (opomba se nadaljuje na naslednji strani) 
je v Porabju bolj razširjena nemščina, kar nas ne preseneča glede na prisotnost tujega kapitala v Monoštru in geografske bližine Avstrije, ki v zadnjih letih postaja pomembna destinacija zaposlovanja. Med anketiranimi jih je le 10,5 \% ocenilo svoje znanje angleščine kot dobro ali srednje dobro, znanje nemščine pa kar 43,3 \%. Ti podatki kažejo očitno povezavo med jezikom in ekonomijo.

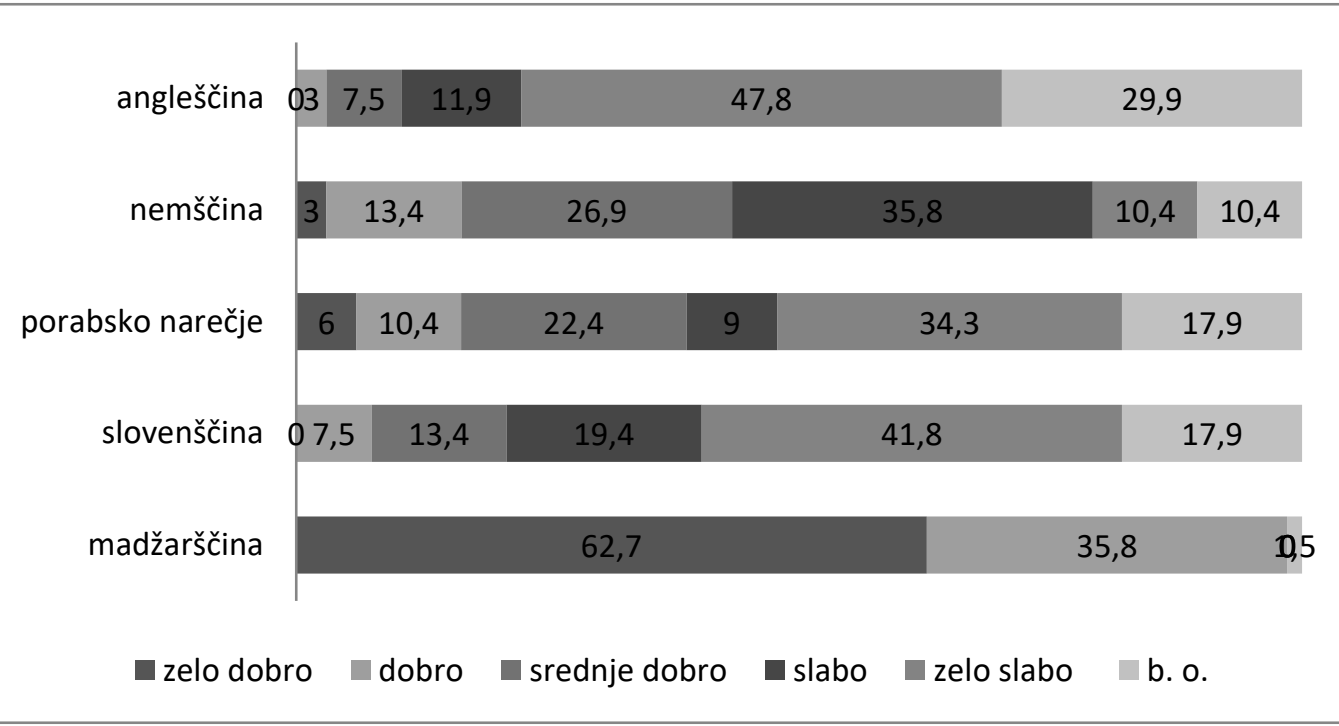

Slika 3: Odgovori na vprašanje, kako sami ocenjujejo lastno znanje jezikov (izraženo v odstotkih, $\mathrm{N}=67$ ).

Odgovori anketiranih o rabi jezikov v družini (Slika 4) kažejo očitno prevlado madžarskega jezika pri vseh sogovorcih. Največ vprašanih, to je 86,5 \%, uporablja večinoma oziroma samo madžarski jezik s partnerjem ali možem, $83,6 \%$ z otroki, 77,6 \% z bratom ali sestro in enak odstotek s sorodniki, 73,1 \% z materjo in 59,7 \% z očetom. Še največ slovenščine uporabljajo anketirani pri sporazumevanju s sorodniki, takih je 7,5 \%, v še manjši meri pa je slovenščina

šolah, potem pa naj izdela srednjeročno strategijo za učinkovitejši pouk tujih jezikov (20182027) in načrt za implementacijo te strategije. Za izvedbo teh nalog je dobilo ministrstvo eno leto (Madžari zelo slabo govorijo tuje jezike, 2017). 
prisotna pri sporazumevanju z mamo ( $6 \%$ oziroma 4 osebe). Med anketiranimi se nihče ne pogovarja $\mathrm{z}$ otroki samo oziroma večinoma $\mathrm{v}$ slovenskem jeziku. 9 \% vprašanih uporablja pri sporazumevanju z materjo oba jezika v enaki meri in v enakem odstotku s sorodniki, v še manjši meri sta prisotna oba jezika pri sporazumevanju z otroki (7,5 \% oziroma 5 oseb), s partnerji (6 \%) in z bratom ali sestro (6 \%). Ti podatki kažejo na popolno prekinitev prenosa porabskega/slovenskega jezika na otroka. Vzroke za prekinitev jezikovne kontinuitete bomo predstavili na koncu prispevka.

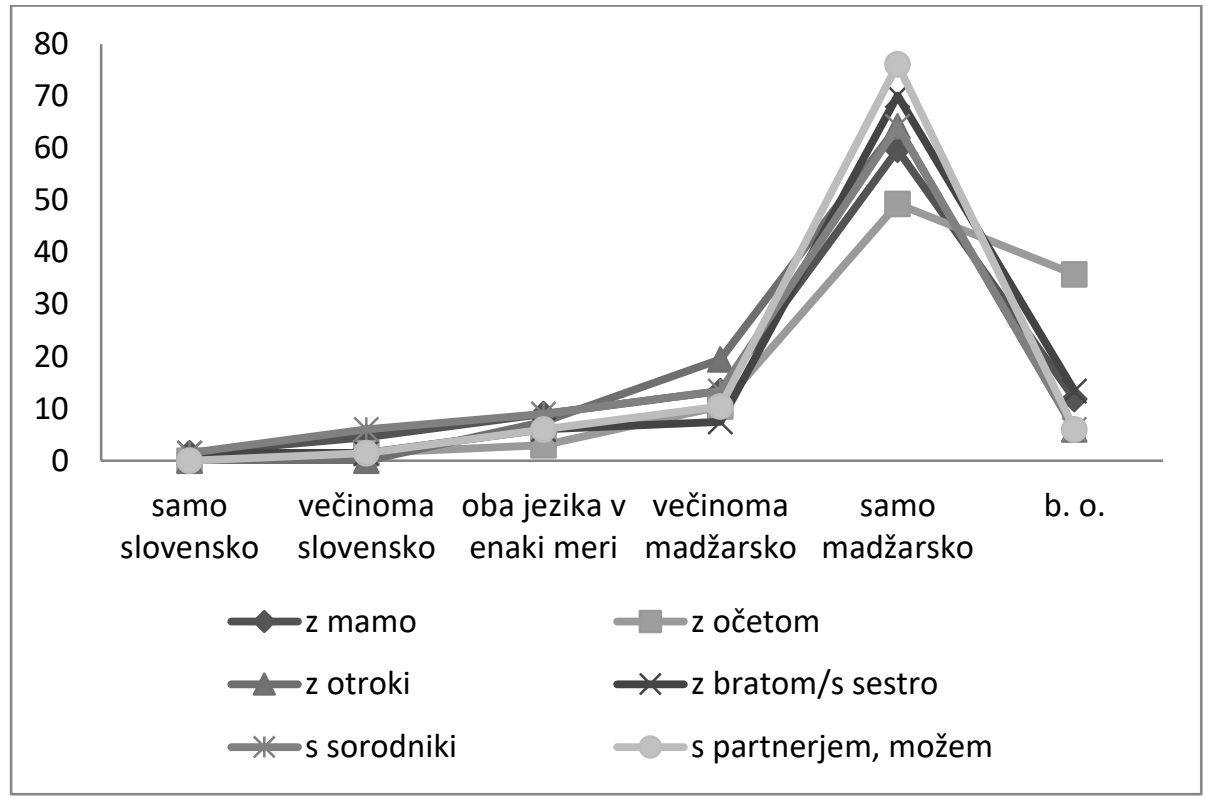

Slika 4: Odgovori na vprašanje, kateri jezik večinoma uporabljajo v družini (izraženo v odstotkih, $\mathrm{N}=67$ ).

Jezikovna zmožnost je tesno povezana tudi $\mathrm{z}$ uspešnostjo vzgojnoizobraževalnega sistema. Na stopnjo jezikovne zmožnosti močno vplivata cilj izobraževanja in položaj posameznega jezika v njem (večinskega, manjšinskega in tujega). V Porabju je pet že omenjenih narodnostnih vrtcev, kjer je bila v preteklosti količina rabe slovenskega jezika odvisna od jezikovne usposobljenosti vzgojiteljic in njihovih govornih navad oziroma odnosa do 
slovenskega jezika. Od prihoda vzgojiteljic asistentk iz Slovenije je slovenski jezik vsakodnevno prisoten pri različnih aktivnostih otrok. Ob izvedbi terenske raziskave je omenjene vrtce obiskovalo približno 80 otrok. Podatki o rabi jezika v družini kažejo, da se je prenos manjšinskega jezika s staršev na otroke popolnoma pretrgal (nihče izmed staršev pri sporazumevanju z otroki ne uporablja samo ali večinoma manjšinskega jezika). Posledično otroci prihajajo $\mathrm{v}$ vrtce brez kakršnega koli znanja porabskega narečja ali knjižne slovenščine. V tej situaciji imajo vzgojno-izobraževalne institucije, v konkretnem primeru vrtci, težko nalogo, kajti na eni strani morajo poskrbeti, da otroke motivirajo za učenje slovenskega jezika, na drugi strani pa morajo spodbuditi starše k rabi narečja v družini in jih ozaveščati, da učenje slovenskega jezika za otroka lahko predstavlja določeno prednost (npr. možnost študija v Sloveniji). Vrtci (in tudi šole) v Porabju so bili v preteklosti pod pritiskom predpisov večinske države, ki so omejevali prisotnost in rabo porabskega narečja, $\mathrm{v}$ učnih jezikovnih programih se je uvedla knjižna standardna varianta jezika, ki se je $\mathrm{v}$ praksi pokazala kot otežujoč dejavnik pri usvojitvi slovenskega jezika. Tako so na primer izsledki sociološke raziskave Madžari in Slovenci (1984) opozorili na zelo nizko stopnjo znanja slovenskega jezika in madžarskega knjižnega jezika pri osnovnošolski populaciji na Gornjem Seniku ter počasen premik iz enojezičnosti v dvojezičnost (Győri-Nagy 1987: 547). Temu je botrovala tudi kadrovska podhranjenost usposobljenih dvojezičnih učiteljev, čemur smo priča še danes.

Po spremenjenih družbenih razmerah $\mathrm{v}$ drugi polovici devetdesetih let dvajsetega stoletja so rabo porabskega narečja ponovno priporočali vzgojiteljicam pri dejavnostih v slovenskem jeziku, zavest o njegovi primernosti za rabo v vrtcih pa se je pri domačih vzgojiteljicah okrepila šele s prihodom vzgojiteljic iz Prekmurja, ki so tudi govorile narečje (Perger 2009: 349-350). Skromna slovenska jezikovna kompetenca domačih vzgojiteljic in popolna odsotnost slovenskih govornih navad v vrtcih vpliva na to, koliko in kako se otroci v narodnostnih vrtcih naučijo slovenskega jezika, zato je pomembna 
strokovna pomoč vzgojiteljic asistentk iz Slovenije (Perger 2016/2017: 174). Od leta 2016 v porabske vrtce prihajata dve vzgojiteljici asistentki, ${ }^{11}$ ki delujeta $\mathrm{v}$ vsakem vrtcu po dva dni v tednu in skrbita za doslednejšo izvedbo slovenskih aktivnosti. "Izvajamo več vrst dejavnosti, poudarek pa je vsekakor na slovenskem jeziku. Pripovedujemo pravljice in se igramo rajalne igre $v$ slovenščini. Sem spadajo še razne izštevanke, prstne igre in bibarije. Predvsem gre za bolj preproste stvari, ki si jih lažje zapomnijo, « je o svojem delu za tednik Porabje spregovorila Maja Mencinger. Njen glavni cilj pa je vključitev staršev in starih staršev v učne procese (Mukič 2016: 3). Podoben cilj si je zadala druga vzgojiteljica asistentka Nataša Jelenovec s pomočjo t. i. slovenske bralne vrečke: »V vrečkije bila slovenska slikanica, zvezek in igrača, za katero je otrok doma skrbel čez teden. Potem so starši ali stari starši - po svojih zmožnostih - prebrali to slikanico. Malčki so slišano narisali $v$ zvezek, $k i$ so ga potem prinesli s to vrečko nazaj $v$ vrtec. Ob sredah smo to vrečko pregledali in določili, kam bo potovala naslednji teden."

V letu 2017 strokovno asistentsko delo opravljata vzgojiteljici iz Slovenije, Andreja Serdt Maučec in Romana Trafela, ki sta strokovno pomoč v porabskih vrtcih že izvajali v preteklosti. Evalvacija strokovnega dela pedagoških asistentov kaže, da si obe prizadevata za čim več slovenskega jezika v vrtcih slovenski jezik redno uporabljata pri sporazumevanju $\mathrm{z}$ domačimi vzgojiteljicami, čim več poskušata slovensko govoriti z otroki, navezali sta stike s starši ipd. Kot negativno vidita predvsem pomanjkanje sporazumevanja v slovenščini zunaj vrtca, v družinah (Perger 2017: 3).

K širjenju slovenskega besednega zaklada malčkov prav gotovo prispevajo tudi različne dejavnosti zunaj vrtca, kot so delavnice na Slovenski vzorčni kmetiji, ${ }^{12}$

\footnotetext{
${ }_{11}$ Vsakodnevni obisk vzgojiteljic je do konca leta 2016 finančno pokrival Urad Vlade RS za Slovence v zamejstvu in po svetu, sedaj pa je plačnik MIZŠ. Pred tem so imeli v petih porabskih vrtcih eno vzgojiteljico asistentko iz Slovenije, ki je bila prisotna po en dan $\mathrm{v}$ vsakem vrtcu.

${ }_{12}$ Slovenska vzorčna kmetija na Gornjem Seniku, odprta leta 2015, ponuja različne zanimive (opomba se nadaljuje na naslednji strani)
} 
prireditve za malčke v organizaciji manjšinskih organizacij, ${ }^{13}$ gostovanja gledaliških skupin iz Slovenije, izleti v Slovenijo, če naštejemo le nekatere. O omenjenih dejavnostih se redno poroča v tedniku Porabje.

V okviru raziskave nas je zanimalo, kako so starši zadovoljni s prisotnostjo, količino rabe in načinom učenja slovenskega jezika $\mathrm{v}$ vrtcih, $\mathrm{z}$ znanjem slovenskega jezika domačih vzgojiteljic in otrok ter s prisotnostjo vzgojiteljice iz Slovenije.

Iz Slike 5 je razvidno, da je večina anketiranih zelo zadovoljnih oziroma zadovoljnih z navedenimi trditvami, kajti odstotek se giblje od 80,6 do 94 . Anketirani so najmanjše zadovoljstvo izrazili glede znanja slovenščine otroka, saj je bilo takih 80,6 \%. Prav tako je bilo pri tej trditvi največ neodločenih (9 \%) in nezadovoljnih (6 \%). Ti podatki nakazujejo, da se starši zavedajo, da je znanje slovenščine njihovih otrok preskromno, a se nam ob tem zastavlja vprašanje, zakaj tisti starši, ki še znajo porabsko narečje, svojih otrok ne naučijo slovensko in jim ne privzgojijo pozitivnega odnosa do jezika. »Otroke je treba pripraviti za učenje narodnostnega jezika, da bi negovali tradicije in običaje, ki so del narodnostnega življenja, " je povedal anketiranec GS8,14 ki se zaveda, da je za ohranjanje manjšinskega jezika odgovorna $v$ prvi vrsti družina. Pričakovanje, da bodo to odgovornost prevzele izobraževalne institucije, na primer vrtci ali šola, vodi v popolno jezikovno asimilacijo (Perger 2015: 86). Domej (2015: 59) pa je poudaril, da je za ohranitev manjšinskega jezika treba vložiti več truda kot za ohranitev večinskega. Tega dejstva bi se morale zavedati dvo- ali večjezične družine, ki hočejo otrokom posredovati dva ali celo več jezikov. Otroci imajo zunaj družine številne možnosti, da se jezikovno urijo v večinskem jeziku, manj pa je možnosti za poglabljanje znanja manjšinskega

prireditve (tudi izobraževalne) za najmlajšo populacijo.

$13 \mathrm{~V}$ okviru sodelovanja med Zvezo Slovencev na Madžarskem in porabskimi vrtci so bile na primer v letu 2017 organizirane različne delavnice za porabske predšolske otroke (S kravo Cifro na kmetijo, Porabje, 27 (22): 3; S kravo Cifro na kmetijo, Porabje, 27 (26): 12).

14 Anketirane smo označili s kraticami po krajih, kjer je bila izvedena anketa $(M=$ Monošter, GS = Gornji Senik, DS = Dolnji Senik, S = Sakalovci, $\mathrm{S}=$ Števanovci). 
jezika. Zato je treba dati manjšinskemu jeziku v družinskem krogu močnejšo oporo kot večinskemu, če hočemo, da ga bo nekoč otrok obvladal približno enako dobro kot dominantni jezik. Domejeva stališča o pomembnosti družine pri ohranjanju manjšinskega jezika bi morale ponotranjiti tudi slovenske družine v Porabju.

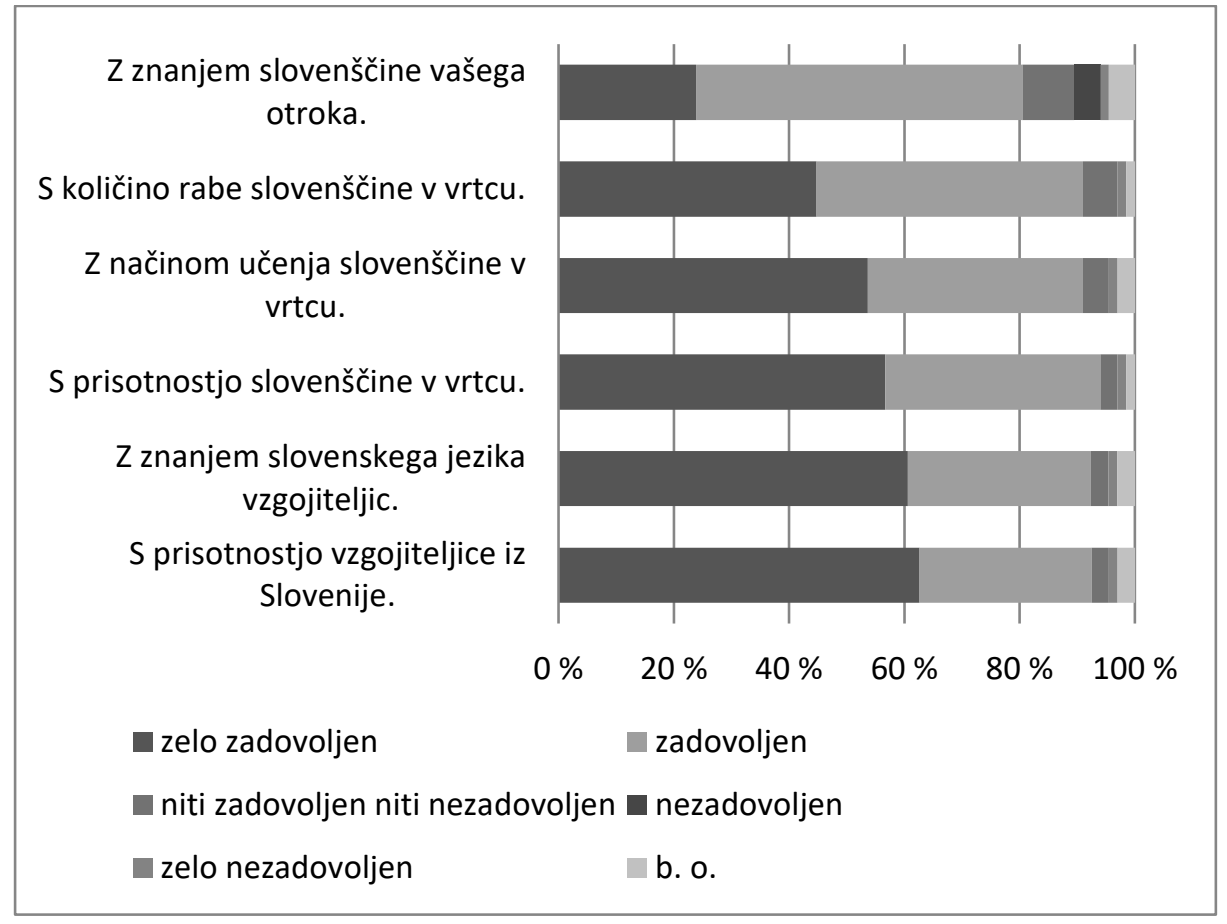

Slika 5: Odgovori na vprašanje, kako so v vrtcu zadovoljni ... (izraženo v odstotkih, $\mathrm{N}=67)$.

Starši so na vprašanje, ali se jim zdi učenje slovenskega jezika pomembno za otroka (Slika 6), v veliki večini (85,1 \%) odgovorili pritrdilno, le zanemarljivim 4,5 \% staršem se to ne zdi pomembno, 7,5 \% vprašanih pa na to vprašanje ni znalo odgovoriti. Pozitivna naravnanost staršev do slovenskega jezika je lahko dobra podlaga za revitalizacijo slovenskega jezika v Porabju. Zato bi morala slovenska skupnost v Porabju v središče razvojnega koncepta postaviti družino in sosesko ter razvijati pozitivna stališča do jezika manjšine, še zlasti do rabe 
porabskega narečja. Manjšinske organizacije bi morale v sodelovanju s stroko z različnih področij intenzivneje izvajati aktivnosti za jezikovno ozaveščanje.

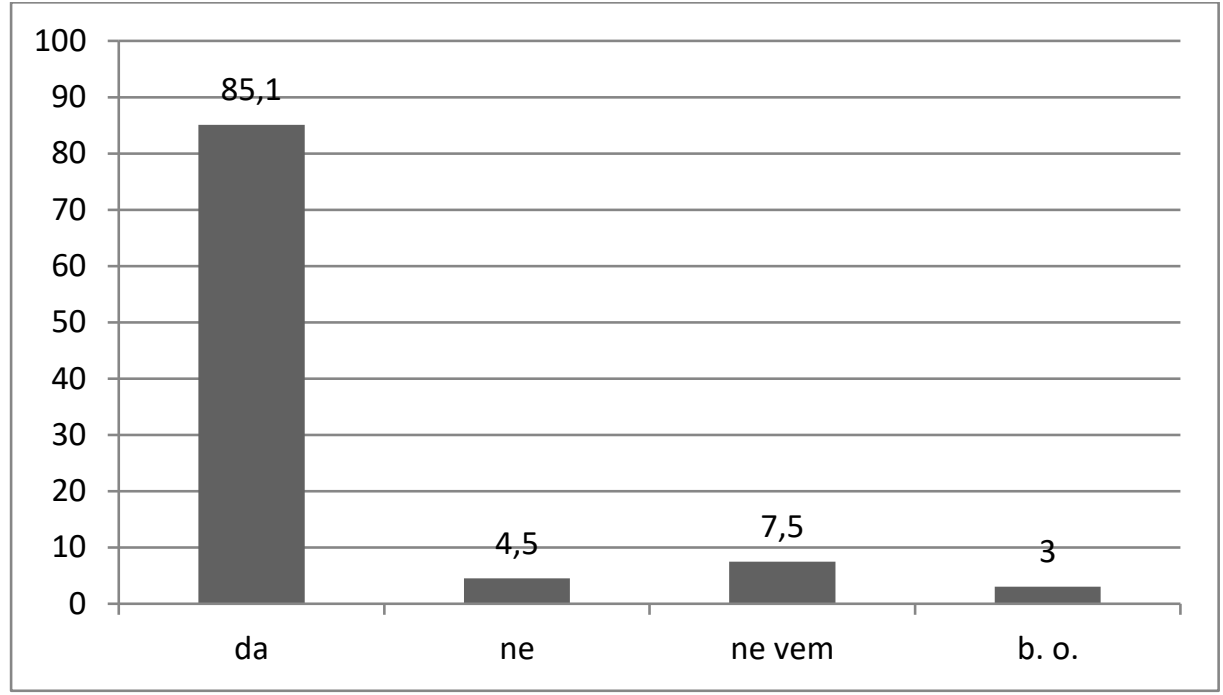

Slika 6: Odgovori na vprašanje, ali se jim zdi učenje slovenskega jezika za otroka pomembno (izraženo v odstotkih, $\mathrm{N}=67$ ).

Odgovore staršev na vprašanje, zakaj menijo, da je znanje slovenskega jezika pomembno (Slika 7), vprašanje je bilo odprtega tipa, smo uvrstili v pet kategorij. Dobra tretjina vprašanih, to je 35,8 \%, je odgovorila, da je znanje jezikov vrednota in koristno - v smislu univerzalne vrednote. Približno 18 \% vprašanih je odgovorilo, da je slovenščina jezik družine, sorodnikov in naših krajev. Za ilustracijo navajamo nekaj odgovorov:

»Stari starši mojih otrok znajo slovensko, rad(a) bi, da bi se tudi moj otrok naučil jezika.» (M9)

»Živimo v Porabju, radi bi, da bi se naš otrok malo seznanil z jezikom.» (M19)

»Ker je bilo tudi za moje starše pomembno. Veseli me, da se lahko tudi moj otrok uči slovensko.» $(\mathrm{S} 1)$

Slabim 12 \% vprašanih se zdi slovenščina pomembna zaradi bližine meje in le 3 
(4,5 \%) vprašanim se zdi slovenščina pomembna zaradi zaposlitve ali študija. Glede na odprtost meje in stikov prebivalcev Porabja s Slovenijo, ki so v zadnjih dveh desetletjih, zlasti pa po letu 2004, oživeli in se razvili tako rekoč na vseh področjih, na političnem, kulturnem, šolskem, znanstvenem, medijskem, športnem, verskem ipd. (Munda Hirnök 2009: 320-321), bi pričakovali večji delež vprašanih, ki bi se zavedali pomembnosti znanja slovenskega jezika zaradi bližine meje v smislu, kot sta odgovorila anketirana: „Znanje slovenskega jezika je pomembno zaradi tega, ker je Slovenija sosednja država, zato menim, da bi se spodobilo znati vsaj osnove." (M16)

»Zaradi bližine slovenske meje je pomembno, da bi razumeli, govorili jezik bližnjih držav." (DS9)

Ker je slovenskih naložb v Porabju premalo, anketirani očitno ne zaznavajo ekonomske vrednosti slovenskega jezika. Podatek, da porabski dijaki ne izkoristijo v dovoljšnji meri možnosti za različna izobraževanja (študij, poletna šola ipd.), ki jim jih ponuja Slovenija, ${ }^{15}$ pa potrjuje, da izobraževanje otrok v slovenskem jeziku za starše ne predstavlja perspektivne izbire. Po tranziciji se je s prihodom tujega kapitala v Monošter močno povečalo zanimanje za učenje tujih jezikov (nemščina, angleščina), slovenščina pa zaradi že prej omenjene odsotnosti slovenskega kapitala in zaradi nerazvitega sosednjega Goričkega ${ }^{16}$ še vedno nima ekonomske moči. Veliko porabskih Slovencev, zlasti mladih, se zaradi bolje plačanih delovnih mest zaposluje v bližnji Avstriji (na Gradiščanskem). Čezmejno zaposlovanje na eni strani prinaša boljše preživetje, na drugi strani pa (lahko) prispeva k spreminjanju etničnih značilnosti porabskih Slovencev. Tukaj je treba pripomniti, da terenske izkušnje kažejo, da je večina mladih, ki so se izobraževali v Sloveniji, po vrnitvi v Porabje dobila zaposlitev prav zaradi znanja slovenščine. Občasno naletimo tudi na oglase v

\footnotetext{
15 Glej Resolucijo o Nacionalnem programu za jezikovno politiko 2014-2018 (2013).

16 Gospodarski kazalniki Goričkega v Sloveniji kažejo, da gre prav tako za periferno območje z enim urbanim središčem in omejenim številom delovnih mest, zaradi česar sta tudi zanj značilna tradicionalno sezonsko, začasno ali stalno izseljevanje in posledično depopulacija prostora (Zupančič 2003: 82-83; Kovács 2016).
} 
tedniku Porabje, ko multinacionalna podjetja s sedežem v Budimpešti ali v drugih večjih mestih na Madžarskem iščejo delavce tudi z znanjem slovenskega jezika (Oglas/Hirdetés 2017).

Nekaj manj kot tretjina vprašanih na vprašanje ni odgovorila, zato o vzrokih za to lahko le ugibamo. Dejstvo pa je, da odprta vprašanja v primerjavi z zaprtimi vprašanji zahtevajo od posameznika več miselnega napora in tudi časa.

Znanje jezikov je vrednota in je koristno.

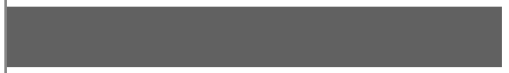

b. o.

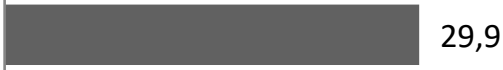

Slovenščina je jezik moje družine, sorodnikov, naših krajev.

Znanje slovenščine je pomembno zaradi bližine meje.

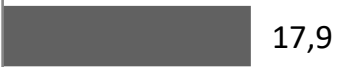

Slovenščina je pomembna zaradi zaposlitve ali študija.

Slika 7: Odgovori na vprašanje, zakaj menijo, da je znanje slovenskega jezika pomembno (izraženo v odstotkih, $\mathrm{N}=67$ ).

$\mathrm{V}$ okviru raziskave nas je zanimala tudi navzočnost tujih jezikov $\mathrm{v}$ vrtcih. Odgovori vprašanih na vprašanje, ali se njihov otrok uči še kakšen drug jezik (Slika 8), kažejo, da se večina malčkov ne uči tujih jezikov. To potrjuje velik delež anketiranih (71,3\%), ki na vprašanje niso odgovorili. Le dobra petina staršev je odgovorila, da se njihovi otroci učijo nemški jezik. Predvidevamo, da gre za otroke, ki obiskujejo vrtec na Dolnjem Seniku, kjer je nemščina zaradi 
pripadnikov nemške narodne skupnosti ${ }^{17}$ prisotna v programu vrtca in za posamezne otroke t. i. slovenske vrtčevske skupine v Monoštru. Odgovore nekaj posameznikov ( 4 oseb oziroma $6 \%$ ) smo uvrstili v kategorijo drugo. ${ }^{18}$

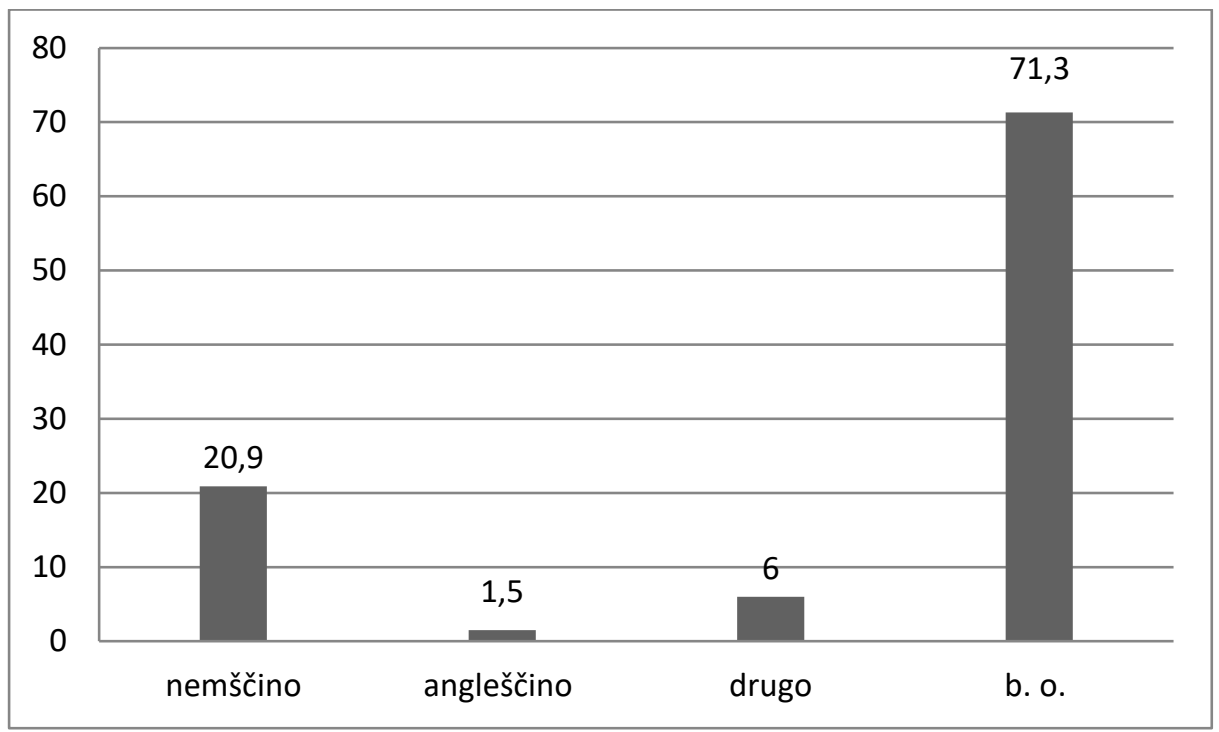

Slika 8: Odgovori na vprašanje, katere jezike se učijo otroci v vrtcu (izraženo v odstotkih, $\mathrm{N}=67$ ).

Kljub odprti meji, povečanju čezmejnih stikov s sosednjima Slovenijo in Avstrijo ter raznovrstni mobilnosti so med prebivalci Porabja, tudi med mladimi, še zmeraj prisotna stališča, da je hkratno učenje več jezikov za otroka obremenitev. To potrjuje tudi odlomek iz intervjuja, ki je nastal v okviru raziskave o mladih v slovenskem zamejstvu leta 2016.19 Intervjuvanec M5 (dijak, 18 let) je na vprašanje, ali meni, da je učenje dveh, treh jezikov dodatna

\footnotetext{
${ }_{17} \mathrm{Za}$ etnično podobo Dolnjega Senika je značilno, da tam že stoletja prebivajo Slovenci, Madžari in Nemci.

18 Trije anketirani so odgovoril, da se otrok še ne uči drugega jezika, v šoli se bo začel učiti nemški jezik, en anketiranec pa je odgovoril, da se otrok ne uči tujega jezika, toda rad bi, da bi se otrok učil nemško ali angleško.

19 Raziskovalni projekt Mladi $v$ slovenskem zamejstvu: družbeni in kulturni konteksti ter sodobni izzivi je potekal na Inštitutu za narodnostna vprašanja v letih 2013-2016, vodila ga je dr. Vera Kržišnik-Bukič. V okviru tega projekta je bilo izvedenih šest intervjujev z mladimi v Porabju.
} 
obremenitev za otroka, odgovoril pritrdilno. Nadaljnje vprašanje je bilo: »Zakaj? Če bi se ti na primer poleg slovenščine in madžarščine že od malega učil recimo angleško ali nemško, misliš, da jih ne bi usvojil? « Intervjuvanec M5 je odgovoril: »Menim, da ne bi mogel popolnoma usvojiti vsakega. Mogoče bi kakšnega dobro usvojil, drugega pa znatno manj in si ga zaradi tega ne bi upal uporabljati in bi ga sčasoma pozabil.«

Odgovori staršev, ki so bili vključeni v raziskavo Stališča staršev v Porabju do slovenskega jezika oziroma dvo- in večjezičnosti, na vprašanje, ali se jim zdi učenje dveh ali več jezikov v šoli ali vrtcu obremenitev za otroka (Slika 9), kažejo, da so stališča, da je učenje več jezikov obremenitev za otroke, še zmeraj prisotna. Petina vprašanih je namreč odgovorila pritrdilno, približno dve tretjini vprašanih se s to trditvijo ne strinja, slaba desetina pa na vprašanje ni želela odgovoriti. Zato bi bilo treba porabske starše, učitelje in širšo skupnost ozaveščati, da usvajanje dveh ali več jezikov otroku ne škodi, temveč ga bogati in mu odpira nove možnosti ter izzive. Slovenska skupnost v Porabju bi se lahko zgledovala tudi po iniciativi »Dvo- in večjezičnost v družini« ${ }^{20}$, ki so jo izvajali na avstrijskem Koroškem.

${ }^{20} \mathrm{O}$ tem glej podrobneje v Piko - Rustia in dr. 2011. 
Ali se vam zdi učenje dveh ali več jezikov v šoli obremenitev za otroka?

Ali se vam zdi učenje dveh ali več jezikov v vrtcu obremenitev za otroka?

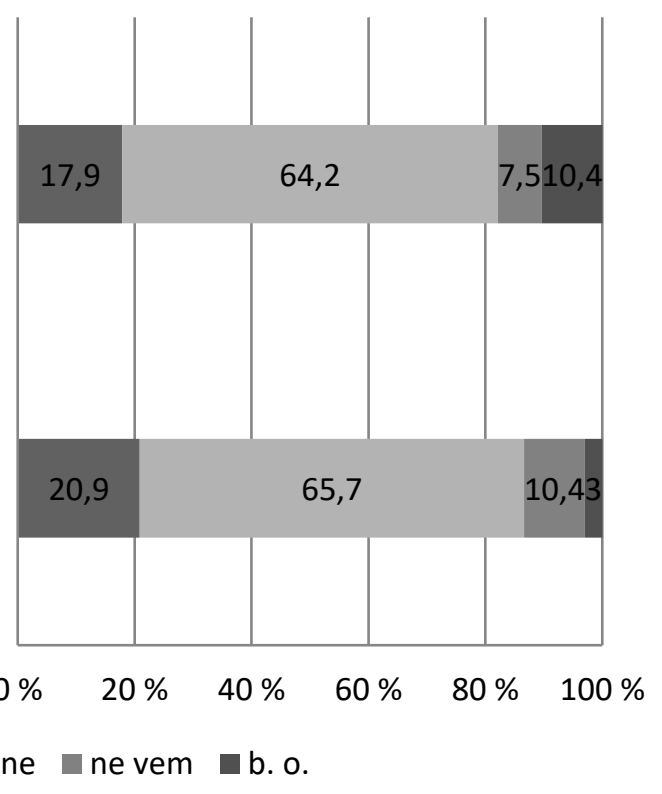

Slika 9: Odgovori na vprašanje, ali se jim zdi učenje jezikov za otroke obremenitev (izraženo v odstotkih, $\mathrm{N}=67$ ).

S sklopom vprašanj smo skušali ugotoviti, kakšno vlogo pripisujejo starši v Porabju slovenskemu jeziku (Slika 10). Večina anketiranih, to je 86,5 \%, je mnenja, da je znanje slovenščine pomembno zaradi možnosti izobraževanja in zaposlovanja, 7,5 \% jih je izrazilo nevtralno stališče in le 2 (3\%) anketirana sta izrazila nasprotno mnenje. Dejansko stanje v Porabju pa ne potrjuje njihovih stališč.

Da je znanje slovenščine potrebno, da se lahko opredeliš kot porabski Slovenec, meni 74,9 \% vprašanih, slaba petina (19,4 \%) je bila pri tej trditvi nevtralna, 9 $\%$ vprašanih pa misli nasprotno.

Večina anketiranih (88,1 \%) se ne strinja oziroma se sploh ne strinja s trditvijo, da učenje slovenščine v vrtcu ni potrebno. Tudi ta trditev je pri $6 \%$ anketiranih naletela na neodločenost. Dobri dve tretjini vprašanih, to je $68,7 \%$, se strinjata $\mathrm{s}$ trditvijo, da je slovenščina pomembna, ker je jezik sosednje države, dobra 
petina (20,9 \%) je izrazila nevtralno stališče, slabih 10 \% pa nestrinjanje. Pri trditvi, da je slovenščina težka, se ni izoblikovalo enotno mnenje $\mathrm{v}$ krogu staršev. Slaba polovica vprašanih, to je 40,3 \%, je bila neodločenih, dobra četrtina $(25,4 \%)$ se je s trditvijo strinjala in prav tako je dobra četrtina $(26,9 \%)$ izrazila nestrinjanje.

Da naj se otroci v vrtcu ali šoli učijo porabsko narečje namesto slovenskega knjižnega jezika, meni slaba četrtina vprašanih, to je 22,4 \%, četrtina (25,4 \%) je izrazila nevtralno stališče, slaba polovica $(47,8 \%)$ pa je izrazila nestrinjanje. Tudi pri trditvi, da je znanje tujih jezikov (nemščine, angleščine) pomembnejše kot znanje slovenščine, se med anketiranimi ni izoblikovalo enotno mnenje. Slaba četrtina vprašanih, to je 23,9 \%, meni, da je znanje tujih jezikov pomembnejše od znanja slovenščine, približno tretjina (32,9 \%) meni nasprotno, slaba polovica $(41,8 \%)$ pa je bila nevtralna pri ocenitvi te trditve.

Večina vprašanih, to je 92,5 \%, se ni strinjala s trditvijo, da učenje slovenskega jezika v vrtcu ali šoli ni potrebno, saj se ga otroci naučijo doma.

Rezultati vprašanj, ki se nanašajo na stališča do slovenskega jezika, kažejo, da večina vprašanih vidi v znanju jezika prednost za poklicno uspešnost, za večino predstavlja dejavnik narodnostne identifikacije in jezik soseda. Vzorci jezikovne rabe so mnogokrat povezani s stališči. Naši podatki pa kažejo, da si stališča in raba jezika v družini ter rezultati pri vprašanju, zakaj se vprašanim zdi znanje slovenskega jezika pomembno za otroka, nasprotujejo. S poglobljenimi intervjuji bi lahko poiskali odgovore, kje in zakaj vprašani ne uporabljajo slovenskega jezika ter zakaj je njihovo znanje slovenščine na tako nizki stopnji, če so pa istočasno njihova stališča do slovenskega jezika pozitivna. 


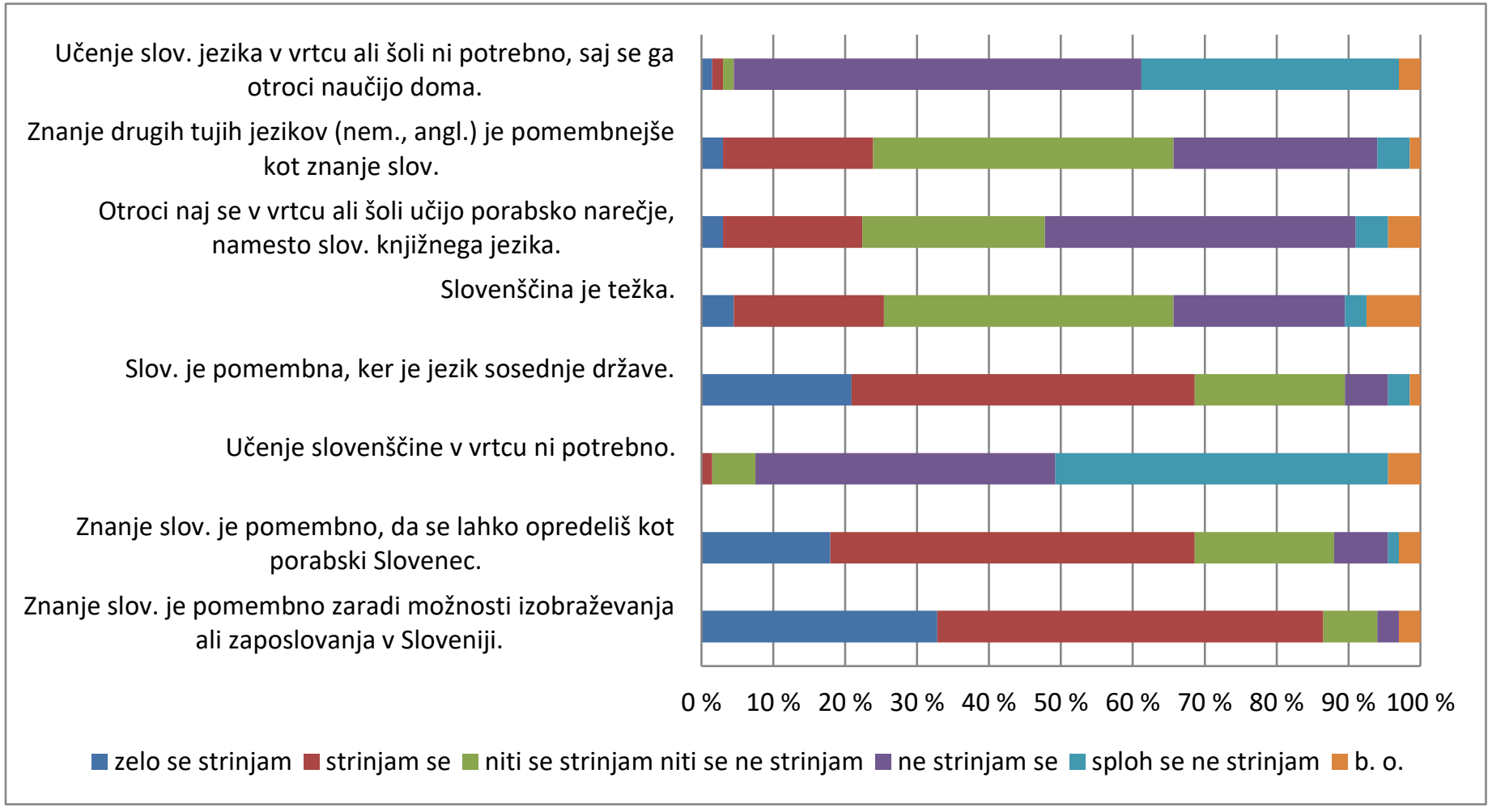

Slika 10: Odgovori na vprašanja, ki se nanašajo na stališča do slovenskega jezika (izraženo v odstotkih, $N=67$ ). 
Anketirane smo povprašali, zakaj se po njihovem mnenju starši z otroki doma ne pogovarjajo slovensko/porabsko (Slika 11). Vprašanje je bilo odprtega tipa. Presenetil nas je velik delež anketiranih (37,3 \%), ki na vprašanje niso odgovorili oziroma niso znali odgovoriti. Slaba tretjina vprašanih, to je 29,8 \%, meni, da starši in mladi ne znajo slovensko/porabsko in da ni medgeneracijskega prenosa, ${ }^{21}$ le 9 \% jih uporablja porabsko narečje in ga ima za živ jezik, 7,5 \% jih meni, da zaradi etnično mešanih zakonov, 13,4 \% pa jih je navedlo druge razloge, ki smo jih združili v kategorijo »drugo«. Odgovori v kategoriji »drugo« nakazujejo prepričanja vprašanih, da »majhnega otroka lahko zmede raba dveh jezikov « in da bi bilo treba porabsko narečje učiti v šoli. Prisotne so še tudi travme iz preteklosti22 in ugotovitve, da današnji moderen svet ni ugoden za ohranjanje slovenskega jezika in da je učenje tujih jezikov (zlasti nemščine, angleščine) bolj perspektivno za otroka. Kot pomemben dejavnik, ki je vplival na to, da se starši z otroki doma niso pogovarjali slovensko/porabsko, je tudi lenoba staršev, kar je poleg travme iz preteklosti zapisal anketiranec z oznako M4: »po mojem mnenju zaradi lenobe', za njih je bilo enostavneje, da so se z nami, otroki, pogovarjali madžarsko, med sabo pa slovensko, zlasti takrat, ko niso hoteli, da bi tudi mi otroci razumeli, o čem se pogovarjajo.«

\footnotetext{
${ }^{21}$ Navajamo nekaj značilnih odgovorov: »Zato ne, ker žal tudi izmed staršev jih zelo malo govori slovensko oziroma v narečju." (DS5)

"Žal zato, ker ne govori veliko ljudi slovensko. Starejši še govorijo slovensko, mlajša generacija pa skoraj ne več.» $\left(\mathrm{S}_{5}\right)$

»Žal jaz ne znam slovensko, kljub temu da moja starša znata. Zelo mi je žal, da se slovenskega jezika nisem naučila, z nami se niso pogovarjali v slovenščini, ampak samo v madžarščini in ne znajo povedati, zakaj.«(M9)

${ }_{22}$ Anketiranec M4 je v svojem odgovoru izpostavil travme iz preteklosti: »Ker so naši starši v šoli znanje narečja doživeli kot handicap, ker so se pogovarjali v narečju, niso znali madžarsko in so se zaradi tega počutili nelagodno.»
} 


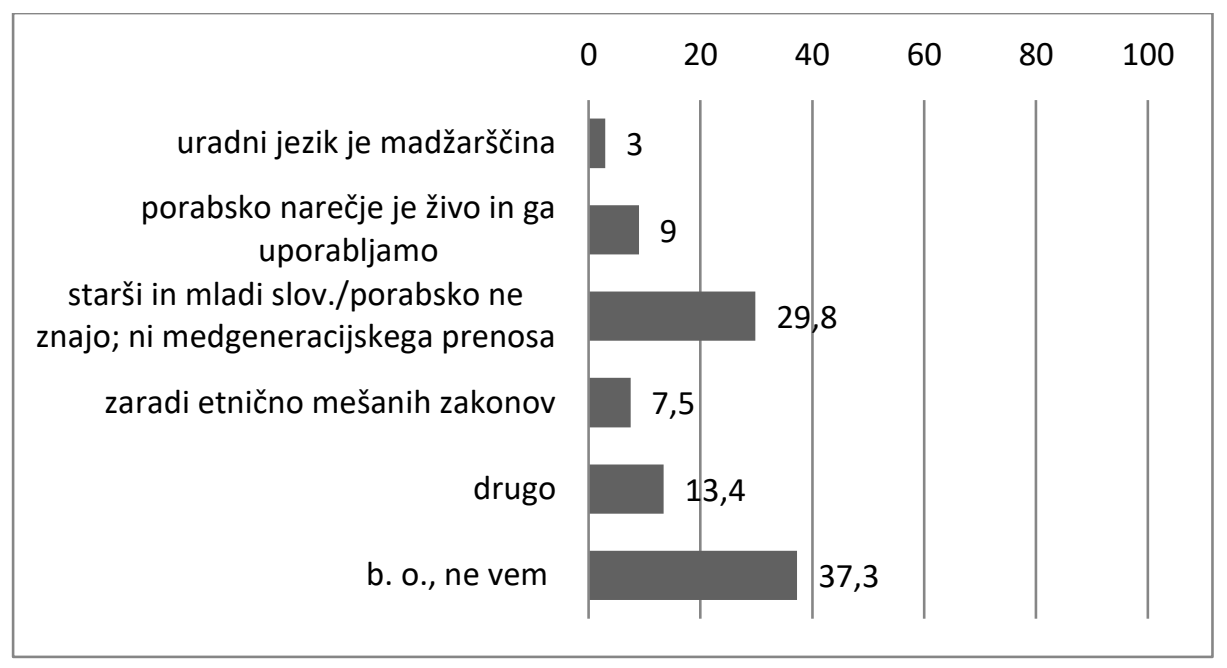

Slika 11: Odgovori na vprašanje, zakaj se po njihovem mnenju v Porabju starši z otroki doma ne pogovarjajo slovensko/porabsko (izraženo v odstotkih, $\mathrm{N}=67$ ).

\section{Sklep}

Odgovori na vprašanja, ki se nanašajo na stališča staršev do slovenskega jezika, kažejo naklonjenost do slovenščine. Večina anketiranih vidi v znanju jezika prednost za poklicno uspešnost, slovenski jezik pa zanje predstavlja tudi identifikacijski dejavnik.

Čeprav velik del anketiranih vidi v znanju slovenskega jezika večplasten pomen, pa tega ne potrjujejo s stopnjo znanja slovenskega jezika in njegove rabe $\mathrm{v}$ družini. Vzorci jezikovne rabe so mnogokrat povezani s stališči. Predstavljeni podatki tega niso pokazali in si celo nasprotujejo. Pri tem se nam zastavljajo vprašanja, ki so povezana $\mathrm{z}$ uspešnostjo izobraževanja in poučevanja $\mathrm{v}$ slovenskem jeziku, s politiko (nacionalno, lokalno), ki bi omogočala rabo jezika na različnih področjih (tudi na gospodarskem) in ozaveščala mlade družine, pa četudi narodnostno mešane, o slovenskem jeziku kot vrednoti ter jih spodbujala $\mathrm{k}$ prenosu tega na svoje otroke.

Analiza odgovorov na vprašanje, zakaj se v Porabju starši z otroki doma ne 
pogovarjajo slovensko/porabsko, je pokazala, da gre za prepletenost neustrezne jezikovne in narodnostne politike ter zgodovinskih in družbenopolitičnih okoliščin, ki so zaznamovale anketirane oziroma prejšnje generacije.

Glede na pridobljene rezultate menimo, da bi bilo treba v prihodnje to tematiko podrobneje raziskati tudi s pomočjo kvalitativnih metod.

\section{LITERAT URA}

Bernjak, E. (2008): Opuščanje manjšinske materinščine in identitete v dvojezičnih skupnostih ob slovensko-madžarski meji. V M. Slavinec (ur.): Zgodovinska identiteta sveta ob Muri: 49-53. Murska Sobota: Pomurska akademsko znanstvena unija.

Bernjak, E. (2012): Etnolingvistična revitalizacija manjšine na Madžarskem. Anali PAZU, 2 (2): 103-107.

Domej, T. (2015): Družina, šola, večjezičnost. V M. Kuchling (ur.):

Slovenščina - živ jezik $v$ družini in javnosti: Prispevki s posveta 14.11. $2014 v$ Katoliškem domu prosvete $v$ Tinjah, Koroška: 55-69. Celovec: Iniciativa Slovenščina v družini/Familiensprache Slowenisch, Krščanska kulturna zveza.

Győri-Nagy, S. (1987): Kétnyelvűség-dinamika Felsőszölnökön. V L. Arday, R. Joó in G. Tarján (ur.): Magyarok és szlovénok: 543-570. Budapest: Állami Gorkij Könyvtár.

Just, F. (2009): Porabje. Murska Sobota: Franc-Franc; Društvo Argo.

Kovács, A. (2007): Številčni razvoj Slovencev v Sombotelu, Budimpešti in Mosonmagyaróváru v luči statističnih podatkov in pričevanj intervjuvancev = A Szombathelyi, Budapesti és Mosonmagyaróvári szlovének számának alakulása a statisztikai adatok és a megkérdezettek válaszainak tükrében. Etnologïa Slovencev na Madžarskem, 5: 41-73.

Kovács, A. (2016): Demografsko praznjenje obmejnega, narodnostno 
mešanega območja v Prekmurju v dvajsetem stoletju - primer dvojezičnih naselij v občini Moravske Toplice. V D. Grafenauer in K. Munda Hirnök (ur.): Raznolikost v etničnosti: izbrani pogledi. Ljubljana: Inštitut za narodnostna vprašanja.

Madžari zelo slabo govorijo tuje jezike (2017). Porabje, 27 (25): 7.

Mukič, D. (2016): V predšolsko jezikovno vzgojo vključiti tudi starše. Porabje, 26 (10): 3 .

Munda Hirnök, K. in Medvešek, M. (2016): Čezmejna mobilnost porabskih Slovencev. Traditiones, 45 (3): 91-113.

Munda Hirnök, K. (1992): Vzroki in razvoj poljedelskega zaposlovanja med porabskimi Slovenci. Razprave in gradivo, 26/27: 238-248.

Munda Hirnök, K. (2009): Porabski Slovenci in čezmejno kulturno sodelovanje - stanje in perspektive. V I. Popov (ur.): Slovenski mikrokozmosi - medetnični in medkulturni odnosi: 20. Slovenski slavistični kongres: zbornik predavanj: 307-323. Ljubljana: Zveza društev Slavistično društvo Slovenije.

Munda Hirnök, K. in Novak Lukanovič, S. (2016): Slovenščina v Porabju: stopnja vitalnosti. V D. Grafenauer in K. Munda Hirnök (ur.): Raznolikost $v$ etničnosti: izbrani pogledi, 192-219. Ljubljana: Inštitut za narodnostna vprašanja.

Nećak Lük, A. (1998): Jezik in etnična pripadnost v Porabju. V A. Nećak Lük in B. Jesih (ur.): Medetnični odnosi v slovenskem etničnem prostoru I: izsledki projekta. Ljubljana: Inštitut za narodnostna vprašanja.

Nećak Lük, A. (2008): Oris jezikovne politike in jezikovnega načrtovanja v panonskem prostoru na dveh tromejah. V V. Klopčič in A. Vratuša (ur.): Živeti z mejo, Panonski prostor in ljudje ob dveh tromejah: zbornik referatov na znanstvenem posvetu $v$ Murski Soboti, 9. -11. novembra 
2007 (Narodne manjšine, 6): 51-73. Ljubljana: Slovenska akademija znanosti in umetnosti, Inštitut za narodnostna vprašanja.

Oglas/Hirdetés (2017). Porabje, 27 (11): 12.

Perger, V. (2009): Vloga porabskega narečja pri ohranjanju narodnostne identitete v Porabju na Madžarskem. V I. Popov (ur.): Slovenski mikrokozmosi - medetnični in medkulturni odnosi. 20. Slovenski slavistični kongres: zbornik predavanj: 343-356. Ljubljana: Zveza društev Slavistično društvo Slovenije.

Perger, V. (2015): Jezik manjšine - živ jezik v družini in javnosti danes in jutri (Tudi v Porabju?). V M. Kuchling (ur.): Slovenščina - živ jezik $v$ družini in javnosti: Prispevki s posveta 14.11. 2014 v Katoliškem domu prosvete $v$ Tinjah, Koroška: 83-89. Celovec: Iniciativa Slovenščina v družini/Familiensprache Slowenisch, Krščanska kulturna zveza.

Perger, V. (2016/2017): Slovenščina v Porabju: narodnostno šolstvo v Porabju na Madžarskem in položaj slovenskega jezika v njem. Signal: das Magazin der Sloweninnen und Slowenen in der Steiermark: 173-177.

Perger, V. (2017): Evalvacija strokovnega dela pedagoških asistentov. Porabje, 27 (27): 3 .

Piko - Rustia, M., in dr. (2011): Dvo- in večjezičnost v družini: 12 spodbud za sožitje v družini = Zwei- und Mehrsprachigkeit in der Familie: 12 Impulse für Sprachenvielfalt der Familie. Celovec; Ljubljana; Dunaj: Mohorjeva družba.

Portfolio. Dostopno prek:

http://www.portfolio.hu/users/elofizetes_info.php?t=cikk\&i=190226 (11. 8. 2017).

Resolucija o Nacionalnem programu za jezikovno politiko 2014-2018 (2013). Uradni list RS, št. 62/13. 
Rosszul járnak a fevételizők: 202O-tól sokkal nehezebb lesz bekerülni egyetemre.

Dostopno prek:

http://eduline.hu/kozoktatas/2017/9/19/2020_erettsegi_kormanyrendelet_HWQ1F8 (25. 9. 2017).

Sukič, M. (2017): Več jezikov znaš, več veljaš? Porabje, 27 (38): 2.

S kravo Cifro na kmetijo (2017). Porabje, 27, (22): 3. (Zapisali: vzgojiteljici asistentki: Andreja in Romana.)

S kravo Cifro na kmetijo (2017). Porabje, 27 (26): 12. (Zapisala: vzgojiteljica Romana.)

Zupančič, J. (1999): Slovenci v Avstriji = The Slovenes in Austria. Ljubljana: Inštitut za geografijo = Institute of Geography.

Zupančič, J. (2003): Čezmejne dnevne migracije v slovenskem obmejnem prostoru. Razprave in gradivo, 43: 68-111. 


\section{ATTITUDES OF PARENTS IN THE PORABJE REGION TOWARDS THE SLOVENE LANGUAGE}

According to the data acquired within the research project Attitudes of parents in the Porabje region towards the Slovene language, bi- and multi-lingualism, despite relatively favourable institutional regulation of minority language following the change of political system in Hungary after 1990, sociolinguistic variables (perception of mother tongue, self-evaluation of language command, communication) for assessing trends of dropping and preservation of the Porabje dialect/Slovene language are worsening as compared to results of the past research studies. However, it is necessary to mention that respondents' attitudes towards Slovene language are positive, the majority seeing language as an advantage in terms of professional success, as a factor of ethnic affiliation and as the language of one's neighbour. Parents consider command of Slovene language important for their children.

Respondents' answers to the open question why parents don't communicate with their children in the Porabje dialect/Slovene language at home provide a convincing description of the reasons having brought about the present situation when the Porabje dialect is considered endangered. That is why with the revitalization of the Porabje dialect/Slovene language special attention will have to be dedicated to respondents - parents, among who there are only $38.8 \%$ that have a good or medium command of the Porabje dialect, and only 20,9\% with good command of literary Slovene, although the majority of the respondents (64\%) declared themselves as Hungarians, and only a quarter $(25,4 \%)$ for Slovenians and Hungarians, and 7,5\% for Slovenians.

A change in the attitude towards minority languages on the part of Slovene community members can in future be due to the planned measures of the Hungarian government (modification of the high schools enrollment decree). According to the document from 2020 on only those secondary school students will be admitted to the first degree or complete university study that passed at least one language examination B2 and at least one graduation examination at 
the higher level. According to the Porabje weekly, it will be a privilege for minority children to be able to pass exam from their mother tongue (as foreign language) which they started learning as small children already, from kindergarten to the secondary school graduation (Sukič: 2017, 2).

Keywords: Hungary, Porabje, Slovene minority, Slovene language, attitudes towards language

To delo je ponujeno pod licenco Creative Commons: Priznanje avtorstvaDeljenje pod enakimi pogoji 4.o Mednarodna.

This work is licensed under the Creative Commons Attribution-ShareAlike 4.0 International.

https://creativecommons.org/licenses/by-sa/4.o/

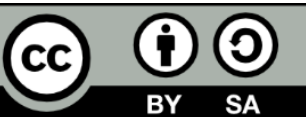

